
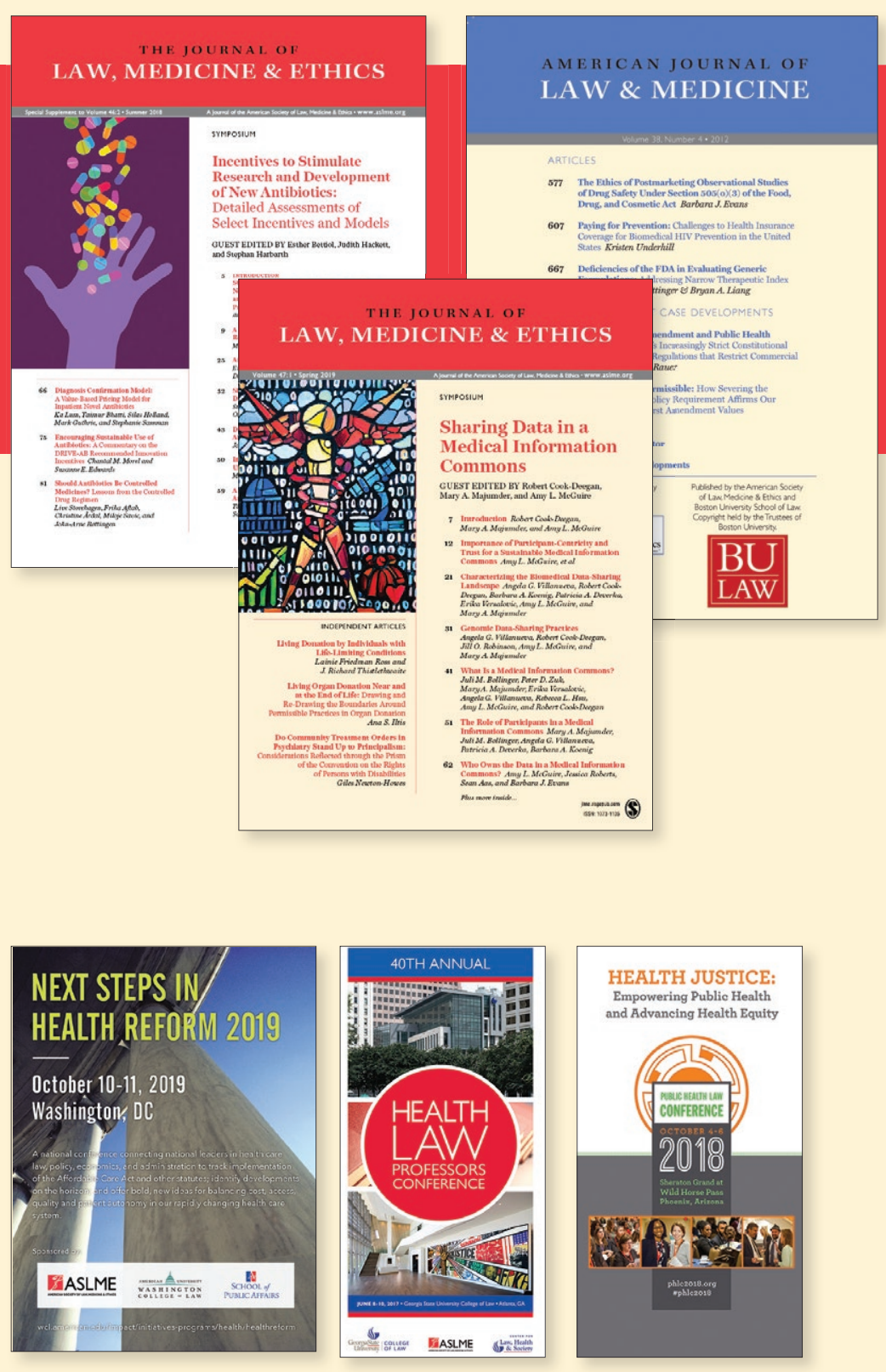

\title{
Membership Benefits
}

- Subscription to the Journal of Law, Medicine \& Ethics

- Subscription to the American Journal of Law \& Medicine

- Discounted registration to Society-sponsored conferences

- Opportunities for earning Continuing Medical and Legal Education credits

- And more!
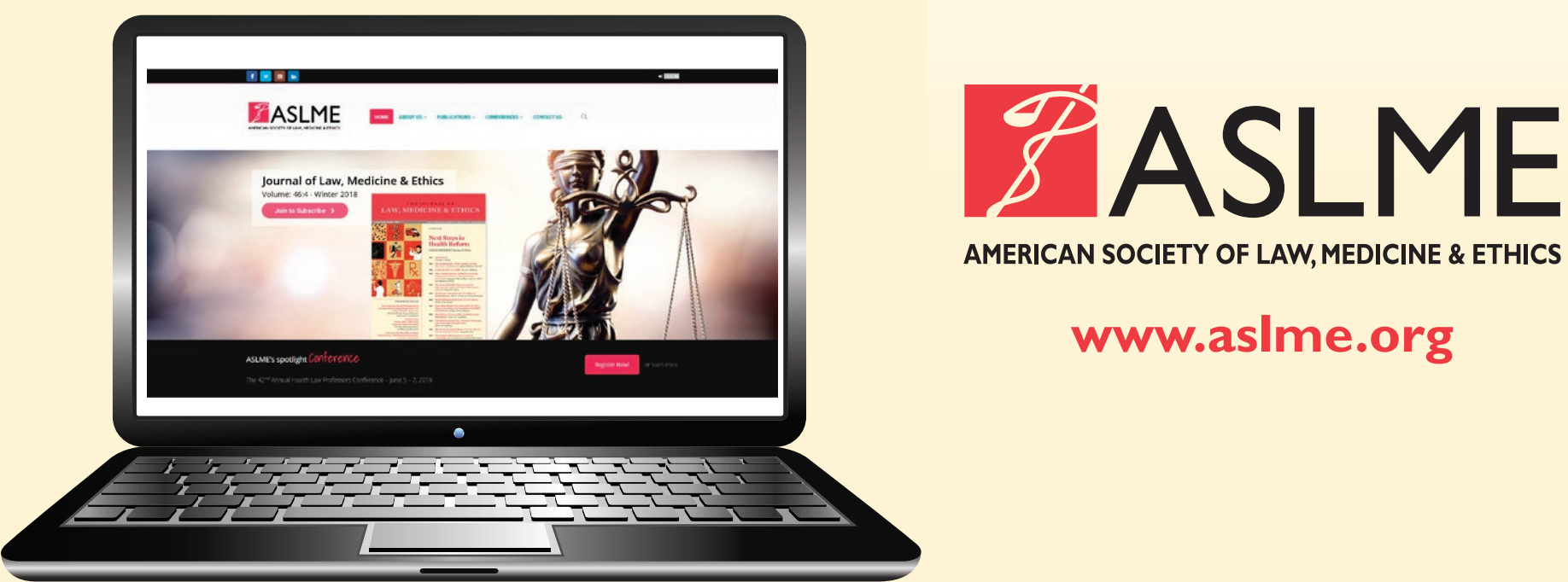

AMERICAN SOCIETY OF LAW, MEDICINE \& ETHICS

www.aslme.org 


\section{Join ASLME today!}

\section{Membership Benefits}

- Subscription to the Journal of Law, Medicine \& Ethics

- Subscription to the American Journal of Law \& Medicine

- Discounted registration to Society-sponsored conferences

- And more!

"Being a member of ASLME pays dividends far beyond its publicized benefits - it is about being part of the major changes in how we think about health care and public health services and delivery through law and ethics."

James G. Hodge, Jr., JD, LLM, Director of the Public Health Law and Policy Program at the Sandra Day O'Connor College of Law, Arizona State University

"My affiliation with ASLME has been among the most satisfying and beneficial relationships in my career."

Judith F. Daar, JD,

Dean of the Salmon P. Chase College of Law at Northern Kentucky University

"Over the two decades of my membership in ASLME, as my career trajectory shifted from cardiac surgery to ethics and philosophy, JLME has been an invaluable companion and component of my ongoing education and continuing contributions to the field of bioethics."

Robert M. Sade, MD, Professor of Surgery at Medical University of South Carolina

\section{Yes, I want to join the American Society of Law,} Medicine \& Ethics.

Please fill out and remit in full to: American Society of Law, Medicine \& Ethics, 765 Commonwealth Avenue, Suite I704, Boston, MA 022 I5. Fax: 617-437-7596 Please print or type all information. You may join online at www.aslme.org.

\section{Questions?}

Contact ASLME at 617-262-4990 or e-mail membership@aslme.org.

Name Suffix/Degrees

Address

City State Zip

Please indicate if the above is your $\square$ Home or $\square$ Business address

Phone

Email

\section{Membership Rates}

\section{Doctoral}

MD, JD, LLB, PhD, DDS, MBA, DNSc, DO, or other equivalent professional position

Non-Doctoral/Allied Health e.g., RN, MSW, MA

\section{Student}

Full-time, without doctoral-level degree

- Memberships with shipping addresses outside of the U.S. require an additional $\$ 40$ per year shipping fee.

Total:

My check made payable to ASLME is enclosed.

Please charge my Mastercard/Visa/Discover/American Express.

\begin{tabular}{c|c} 
I year & 3 years \\
$\$ 230$ & $\$ 550$
\end{tabular}

$\$ 150$ $\$ 355$ $\$ 25$ $\mathbf{n} / \mathbf{a}$

Exp. date 